\title{
Greener homes: an ex-post estimate of the cost of carbon dioxide emission reduction using administrative micro-data from the Republic of Ireland
}

\author{
Eimear Leahy $\cdot$ Richard S. J. Tol
}

Received: 3 June 2011/Accepted: 24 December 2011/Published online: 25 April 2012

(C) The Author(s) 2012. This article is published with open access at Springerlink.com

\begin{abstract}
We assess the subsidy for the installation of biomass boilers and wood gasification boilers under the Greener Homes Scheme in Ireland. We find that the (implicit) subsidy per tonne of carbon dioxide avoided varies hugely across households. The current policy costs $17 \%$ too much for the emissions avoided, or avoids $17 \%$ too little for the money spent. The subsidy reduces net social gain (including environmental benefits but excluding producer surplus) by $42 \%$.
\end{abstract}

Keywords Climate policy $\cdot$ Ireland $\cdot$ Ex-post evaluation

JEL Classification Q48 · Q54

\section{Introduction}

There are many ex-ante estimates of the costs of greenhouse gas emission reduction (see, for example, Clarke et al. 2009). Most of these studies assume cost-effective implementation of climate policy, although there are also papers that study the effect of one particular deviation from the first best (see, for example, Babiker et al.

\section{E. Leahy}

Fiscal Council, Whitaker Square, Sir John Rogerson's Quay, Dublin 2, Ireland

R. S. J. Tol

Department of Economics, University of Sussex, Mantell Building, Falmer BN1 9RF, UK

R. S. J. Tol

Institute for Environmental Studies, Vrije Universiteit, Amsterdam, The Netherlands

R. S. J. Tol (ه)

Department of Spatial Economics, Vrije Universiteit, Amsterdam, The Netherlands e-mail: r.tol@sussex.ac.uk 
2003). This paper is different. It is ex-post in that it estimates the costs of a policy that has been implemented. The paper focuses on the excess costs of the policy, which was designed in such a clumsy way that no academic economist would ever think of an ex-ante analysis of this kind of intervention. The paper is about a minor subsidy (for biomass heating) in a small country (Ireland), but its implications are wider than that. There is no reason to assume that climate policy would be designed as recommended in an economics textbook. As a result, emission abatement may be considerably more expensive than typically assumed. This paper contributes to the quantification of the excess cost.

The European Union's climate-and-energy package states that renewable energy should account for $20 \%$ of the EU's final energy consumption by 2020. For Ireland, $16 \%$ of the final energy consumption should come from renewables by 2020 (European Commission 2011). The production of renewable energy must come from 3 areas: electricity, heating, and transport. The Greener Homes Scheme (GHS) was introduced in 2006 (and closed in 2011) with the aim of increasing the use of renewable energy and sustainable energy technologies in Irish homes. It thus helps Ireland meet its targets in the Renewable Energy Sources for Heating and Cooling (RES-H) category. The scheme provides a grant to domestic property owners to contribute to the initial capital cost of installing a renewable heating technology. Initially, the scheme was available for residents of both existing and new dwellings; however, in July 2008 the scheme was restricted to existing homes. Between 2006 and 2010, 31,560 households received grants under the scheme. As much as $59 \%$ of the households availing of the scheme installed solar thermal, $20 \%$ installed biomass stoves and boilers, $20 \%$ installed heat pumps and less than $1 \%$ installed wood gasification boilers. The total amount offered in grants between 2006 and 2010 was approximately €68.4 million. Was this money spent wisely? Could the same money have avoided more emissions? Could the same emissions be avoided for less money? In this paper, we answer those questions for biomass boilers.

We limit ourselves to biomass boilers because these replace previous heating systems. Heat pumps provide supplemental heat, and therefore reduce only a fraction of the carbon dioxide emissions from heating. That fraction is unknown to us. Solar thermal provides supplemental heat, replacing an, to us, unknown share of heat supply. These restrictions bias our conclusions. Ireland has a maritime climate with limited variation in temperature between summer and winter. Heat pumps are therefore not very effective. Ireland is also not optimal for solar thermal. In our analysis, we ignore the fact that $79 \%$ of the subsidy was spent on less suited technologies.

The GHS is only one of the three schemes aimed at reducing emissions by changing and reducing energy use in the residential sector in Ireland. The Warmer Homes Scheme (WHS) aims to improve the energy efficiency and comfort conditions of the homes of those on low incomes. Measures include the installation of lagging jackets, attic insulation, cavity wall insulation, draught proofing and energy-efficient lighting. Between 2000 and $2008, € 10.9 \mathrm{~m}$ had been allocated to the scheme which covered interventions in about 17,700 households (Department of Social and Family Affairs 2009). The Home Energy Saving Scheme (HES) was launched in March 2009 and is available to the owners of all dwellings built before 2006. Grants are provided for the investment in energy-efficient improvements such 
as roof insulation, wall insulation, installation of high-efficiency boilers or improved heating controls. The energy rating of the building before and after the improvements is compared. Over 111,000 homes had availed of the scheme by the end of 2010 at a cost of over $€ 47$ million (SEAI 2011). Unfortunately, we have access to the administrative data for the GHS only. We therefore do not analyse the WHS or the HES, even though households are entitled to subsidies under both GHS and either WHS or HES.

Besides subsidies for renewable energy technologies, Ireland levies a carbon tax on oil and gas for home heating. Peat and coal are exempt. The oddly designed carbon tax creates its own distortions. It also interacts with the GHS, incentivising those who use the cleaner fossil fuels to switch to biomass energy. We ignore this aspect, noting that we therefore understate the inefficiencies in the GHS.

To our knowledge, we are the first to carry out an assessment of a government run renewable energy scheme for the residential sector in Ireland. There are a number of studies of residential energy use in Ireland, for example, Leahy and Lyons (2010), O’Doherty et al. (2008) and O'Leary et al. (2008). Scott (1997) studied the uptake of energy-saving measures. Clinch and Healy (2001) conduct an ex-ante cost-benefit analysis of the retro-fitting of homes. The study by the Department of Social and Family Affairs (2009) is closest to ours. It carried out an ex-post assessment of the energy, environmental, thermal comfort and health benefits of the WHS. The study was based on a sample of 600 households, 257 of which availed of subsidies under the WHS and 343 which did not (but who did apply). The results show that control group improved the energy efficiency of their houses to roughly the same degree as those that did receive a subsidy, so that there was no significant difference between the control and the policy group with regard to energy use, fuel poverty, comfort and health risks.

The paper continues as follows. Section 2 reviews the literature. Section 3 presents the data and methods used. The results are presented in Sect. 4. Section 5 provides a discussion and conclusion.

\section{Literature review}

There have been ex-post studies of the costs of residential emission reduction for other countries. Jenkins (2010) focused on a scheme that was available to fuel-poor households in the UK. The measures considered were loft insulation, improved lighting, improved glazing, draught proofing, external insulation, and improved boiler and refrigeration. On comparing the results of 3 previous UK studies, Jenkins (2010) finds that the cost of retrofitting a house, assuming that a carbon saving of at least $50 \%$ was achieved, varies from between $£ 7,000$ and $£ 31,900$. The annual cost of saving a tonne of carbon as a result of the retrofit varies between $£ 2,252$ and $£ 10,250$. Mills and Schleich (2009) studied the adoption of solar thermal technologies in the German residential sector. Results show that households can make moderate savings on energy expenditure from combined solar water and space heating systems. However, there is no evidence of savings for those households that install solar technologies for either space or water heating. There is also little 
evidence of differential adoption across socio-economic groups. The authors note low adoption of solar technologies in the German housing market and attribute this to the fixed housing stock and the relatively low savings potential. Amstalden et al. (2007) analysed the profitability, from the homeowner's point of view, of investing in energy-efficient retrofit measures in the Swiss residential market. The authors find that the profitability of the investment is heavily influenced by expected future energy prices. If oil prices are at 2005 levels or higher, the investment in energyefficient retrofit measures would be profitable, even without government supports. Concerning market intervention, a combination of policy options such as subsidies, income tax deductions and a carbon tax would make the investment profitable even when oil prices are relatively low. The authors argue that subsidies alone would not make the investment profitable unless oil prices rise substantially. Wasi and Carson (2011) examine recent rebate programmes aimed at increasing the share of solar/ heat pump systems for the purpose of residential water heating in New South Wales. Using a specifically designed survey, the authors collect information from homeowners who have recently purchased the water heater. They find that the rebate programme increased the share of solar/heat pump systems by $43 \%$ for households who do not have access to natural gas. For those with natural gas access, the programme increased the share of solar/heat pump systems by $19 \%$. It appears that the rebate programmes were important only for those households that deliberately set out to replace their water heater. The rebate programme was much less effective when water heaters were replaced on an emergency basis. Data were also collected on a group of respondents who were likely to replace their water system in the near future. These data were analysed using several flexible choice models. Results show that there is considerable heterogeneity in preferences towards different types of water heaters as well as in the household discount rates. Oritz and Markandya (2009) investigated the cost-effectiveness of different policy options to promote the use of energy-efficient appliances in Europe. The authors analysed energy taxes, subsidies, tax credits and bans. The improvement of refrigerators, washing machines and boilers and the installation of energy-efficient light bulbs in 4 European countries were considered. In each case the reduction in $\mathrm{CO}_{2}$, the administrative costs and the welfare costs and gains were compared. The best policy response was found to depend on the country and the appliance in question. In most cases, subsidies were found to be more expensive than energy taxes. Although subsidies tend to produce larger $\mathrm{CO}_{2}$ reductions, they tend also to be associated with higher welfare costs. Metcalf (2009) analysed the US tax code in relation to low carbon technologies. He argues that subsidies are inefficient because they lower the cost of energy. The consumer is thus encouraged to respond in a manner that contradicts the goal of emission reduction. Metcalf (2009) also makes the point that it is difficult to achieve technology neutrality with subsidies. This argument is most relevant for the GHS where different subsidies are awarded for different technologies and all households are awarded a different price per tonne of carbon avoided. According to Metcalf (2009), the promotion of carbon-free technologies should be done by increasing the price of carbon and not by subsidising clean-energy technologies. 


\section{Data and methods}

We use the anonymised micro-data for the GHS provided by the Sustainable Energy Authority of Ireland (SEAI). The data set contains household information about the amount of the grant provided, the type of product installed, the gross cost of the installation, the size of the dwelling (in square feet or metres), the number of bedrooms, the type of accommodation, the county in which the applicant lives, the date on which the grant is provided and the fuel which is displaced. The data refers to all of the grants that were allocated under the scheme between April 2006 and October 2010. In total, 30,155 households received grants over this period. The demand profile for different technologies over the course of the scheme is displayed in Table 7. Table 8 shows the grants that were available at different time periods. The average installation cost reported by applicants and the expected total cost of the installation, as estimated by SEAI (2010), is also displayed.

First, we compute the average subsidy per tonne of carbon dioxide avoided for each household. Second, assuming unchanged demand, we assess which households would gain or lose if the subsidy amount was based on the amount of $\mathrm{CO}_{2}$ avoided rather than the device. Third, using the price elasticities estimated above, we simulate the changes in demand due to the hypothetical subsidy. Fourth, we calculate the resulting changes in net social gain (excluding producer surplus).

We restrict the sample to those households that availed of grants for biomass boilers and wood gasification boilers. To assess the cost of emission reduction, we impute energy usage, total emissions and the emissions of the displaced fuel for each household in the restricted sample. For this part of the analysis, we incorporate the anonymised 2004/05 Household Budget Survey (HBS) (CSO 2007a) which was carried out on a representative random sample of private households in Ireland. Administered by the Central Statistics Office of Ireland, the main aim of the HBS was to determine household expenditure in order to update the weightings used for the consumer price index. Detailed information is also provided on income and household facilities. In 2004/05, 6,884 private households participated in the survey. Households record expenditure on different fuel types over specified periods, as well as the volume used. ${ }^{1}$ The price of fuel follows. We then impute energy use for households that availed of the GHS by matching households in the HBS to households in the GHS based on variables that are common to both data sets: the type of dwelling, year built, the number of bedrooms and primary heating fuel. Each household in our sample is thus a representative of a group of similar households in the HBS. We estimate the emissions of each fuel type for each household by multiplying the quantity by its emission factor (Scott and Eakins 2004).

\footnotetext{
1 The HBS includes information on energy expenditure in new buildings up to 2004/05. In order to estimate energy use and emissions of dwellings built after this date, we apply energy usage growth factors which are displayed in Table 9. These growth factors are taken from Dineen and Ó'Gallachóir (2011), where the energy consumption of the average newly built dwelling between 1997 and 2020 is estimated. The annual growth and/or decline in the demand for space heating, water heating, lighting and appliances and cooking are separately estimated.
} 
Table 1 Household energy use, electricity use and emissions in the GHS

\begin{tabular}{lrrrrr}
\hline & $\begin{array}{l}\text { Household } \\
\text { energy use } \\
(\mathrm{kWh})\end{array}$ & $\begin{array}{l}\text { Household } \\
\text { electricity } \\
\text { use }(\mathrm{kWh})\end{array}$ & $\begin{array}{l}\text { Household } \\
\text { emissions } \\
\left(\mathrm{tCO}_{2}\right)\end{array}$ & $\begin{array}{l}\text { Emissions of } \\
\text { replaced fuel } \\
\left(\mathrm{tCO}_{2}\right)\end{array}$ & $\begin{array}{l}\text { GHS } \\
\text { subsidy }(€)\end{array}$ \\
\hline Total & $102,905,990$ & $21,499,594$ & 62,938 & 17,383 & $13,515,600$ \\
Average & 29,915 & 6,250 & 18 & 5 & 3,929 \\
Standard deviation & 4,388 & 1,372 & 4 & 2 & 586 \\
Minimum & 13,372 & 0 & 4 & 0 & 2,000 \\
Maximum & 47,796 & 9,647 & 29 & 17 & 4,200 \\
\hline
\end{tabular}

Descriptive statistics on the imputed household energy usage and emissions for the restricted sample are provided in Table 1. The average Irish household used $25,304 \mathrm{kWh}$ of energy annually and emitted $8.1 \mathrm{tCO}_{2}$; average electricity use per annum is 5,591 kWh (O'Leary et al. 2008). ${ }^{2}$ Table 1 shows that the households that availed of grants under the GHS used more energy, more electricity and emitted more $\mathrm{CO}_{2}$ than the average Irish household. Leahy and Lyons (2010) found that electricity usage in Irish homes increases with household income. This is probably because wealthier households have more electrical appliances and may use them more often. Households availing of the GHS use $12 \%$ more electricity than the average household. The average number of bedrooms for households availing of the GHS is 4.2, while the 2004/05 HBS shows that the average household contains 3.4 bedrooms. Also, $95 \%$ of GHS recipients live in detached houses, whereas the 2006 census shows that only $48 \%$ of dwellings in Ireland are detached houses (CSO 2007b). All this indicates that GHS households are relatively rich. While it is encouraging that those households that emit relatively high quantities of $\mathrm{CO}_{2}$ are actively reducing their emissions, it also appears that the grants are being provided to relatively wealthy individuals, who may have invested in renewable technologies in the absence of government supports.

Baumol (1972) showed that, in a cost-effective emission reduction policy, emissions are priced equally at the margin. In GHS, that is not necessarily the case. Subsidies are granted for the purchase of heaters and boilers, rather than for their use. Subsidies are independent of the fuel replaced, the size of house and its energy efficiency. While the subsidy per boiler is the same for each household, the subsidy per tonne of carbon dioxide avoided varies drastically.

Therefore, in the second part of the analysis, we analyse the imposition of subsidies that are proportional to the emissions saved over the lifetime of the renewable technology. We assume that the life of biomass boilers and wood gasification boilers is 20 years and we assume that household emissions are reduced by the same amount each year over the 20-year period. We use a discount rate of $4 \%$ because this is the rate recommended for cost-effectiveness analysis of public sector projects (Department of Finance 2011). Using OLS regressions, we estimate the elasticity of demand with

\footnotetext{
${ }^{2}$ In comparison, the 2004/05 HBS showed that average annual energy usage was 26,139 $\mathrm{kWh}$, while annual electricity use was 4,335 kWh (CSO 2007a).
} 
Table 2 Regression results: dependent variable Ln (quantity sold)

a Different from zero at the $1 \%$ significance level

\begin{tabular}{llllll}
\hline & \multicolumn{2}{l}{ Biomass boilers } & \multicolumn{2}{l}{$\begin{array}{l}\text { Wood gasification } \\
\text { boilers }\end{array}$} \\
\cline { 2 - 3 } \cline { 5 - 6 } \cline { 5 - 6 } & Coef. & SE & & Coef. & SE \\
\hline Ln (net cost) & -0.867 & $0.019^{\mathrm{a}}$ & & -1.863 & $0.111^{\mathrm{a}}$ \\
Year & -0.045 & $0.014^{\mathrm{a}}$ & & 0.062 & 0.066 \\
\# Bedrooms & -0.007 & 0.011 & & -0.053 & 0.038 \\
Type of house dummies & Included & & Included & \\
County dummies & Included & & Included & \\
Adj $R^{2}$ & 0.877 & & 0.457 & \\
$N$ & 3,336 & & & 104 & \\
\hline
\end{tabular}

regard to the net cost of installations ${ }^{3}$ (i.e. the gross installation cost minus the subsidy received $)^{4}$ (see Table 2 ). We predict how households would adjust their demand in response to changes in the level of subsidy. We also estimate the number of households that would have availed of the renewable technologies even if no subsidy had been provided. We also consider more elastic and more inelastic price elasticities and present the resulting changes in the level of demand. In addition, we present the resulting changes in the cost and emission avoidance level.

We consider three arbitrary subsidies: $€ 20 / \mathrm{tCO}_{2}$ (FitzGerald et al. 2008), €15/tCO (the carbon tax that was introduced in December 2009) and $€ 30 / \mathrm{tCO}_{2}$ (the carbon tax proposed for 2014). We also consider "optimum" subsidies. In order to assess environmental efficiency, we derive the maximum amount of emissions that could have been avoided given that the budget for the scheme is $€ 13.5$ million, assuming that each household receives the same subsidy per $\mathrm{tCO}_{2}$ avoided. Similarly, we examine economic efficiency by deriving the degree to which the cost of the scheme could have been reduced while keeping emission reduction at the current level.

Finally, we estimate the consumer surplus that is derived under different subsidy scenarios.

\section{Results}

We present the results in four steps. First, we compute for each household the average subsidy per tonne of carbon dioxide avoided. Second, we assess which

\footnotetext{
${ }^{3}$ Because the net cost is unique to each household, we group the net cost variable into bands of $€ 500$ and we $\log$ the median price in each band. We also log the corresponding demand in each category. Using OLS regressions, we then find the elasticity of demand for biomass and wood gasification boilers.

${ }^{4}$ Occasionally, other refurbishments were carried out in addition to the installation of the renewable technology. It appears that some households may have recorded the gross cost of all work done in the dwelling as opposed to the cost of installing the GHS technology only. In order to minimise the possibility of including incorrect estimates of the net cost, we omit the top $2.5 \%$ and bottom $2.5 \%$ of observations based on the net cost variable. All of the households for which no gross cost is reported are also omitted. The resulting sample contains 3,340 observations with the net cost ranging between $€ 1,100$ and $€ 19,800$.
} 


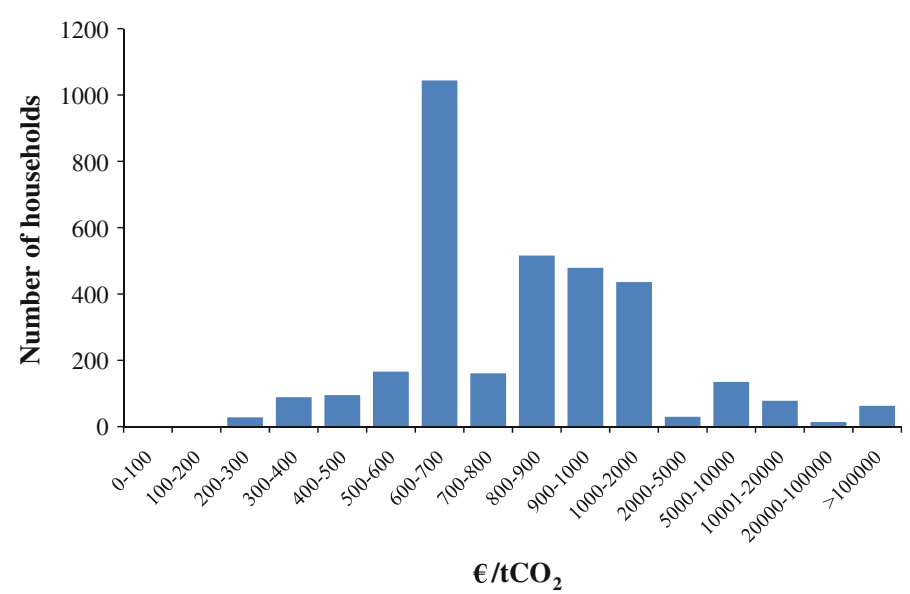

Fig. 1 Cost per $\mathrm{tCO}_{2}$ avoided per household: biomass boilers

households would gain or lose if the subsidy was awarded for the amount of $\mathrm{CO}_{2}$ avoided rather than for purchasing a device. We do this assuming unchanged demand. However, in the third step, using the price elasticities estimated above, we simulate the changes in demand due to the hypothetical subsidy. Fourth, we calculate the resulting changes in net social gain (excluding producer surplus).

\subsection{The costs of emission reduction under the GHS}

Figure 1 shows that the cost per $\mathrm{tCO}_{2}$ avoided varies hugely across the $3,336^{5}$ households that installed biomass boilers. A total of 670 households receive a subsidy of $€ 615 / \mathrm{tCO}_{2}$ avoided and $68 \%$ of households get subsidies even higher than this. The costs of carbon dioxide mitigation for households that installed wood gasification boilers are displayed in Fig. 2; 104 households in the restricted sample availed of these subsidies. ${ }^{6}$ As much as $15 \%$ of households that installed wood gasification boilers get a subsidy of $€ 374 / \mathrm{tCO}_{2}$ avoided and $47 \%$ get subsidies even higher than this. The average cost of carbon dioxide mitigation is almost $38 \%$ higher for biomass than it is for wood gasification boilers.

Table 3 shows the annuitised cost of emission reduction for biomass and wood boilers, assuming a 20-year lifetime and $4 \%$ discount rate. Note that we omit fuel costs for want of information. In each case, the standard deviation far exceeds the mean indicating that the subsidy varies hugely across households. The average annual subsidy for carbon dioxide avoided by the GHS is far higher than the EU ETS permit price which averaged $€ 14 / \mathrm{tCO}_{2}$ in 2010 (Point Carbon 2011) or the carbon tax of $€ 20 / \mathrm{tCO}_{2}$.

\footnotetext{
5 In total, 4,139 households installed biomass boilers; however, when we restricted the sample we lost 803 of these observations.

6113 households in total received grants for wood gasification boilers; however, we omitted some of these observations based on the reported net cost.
} 


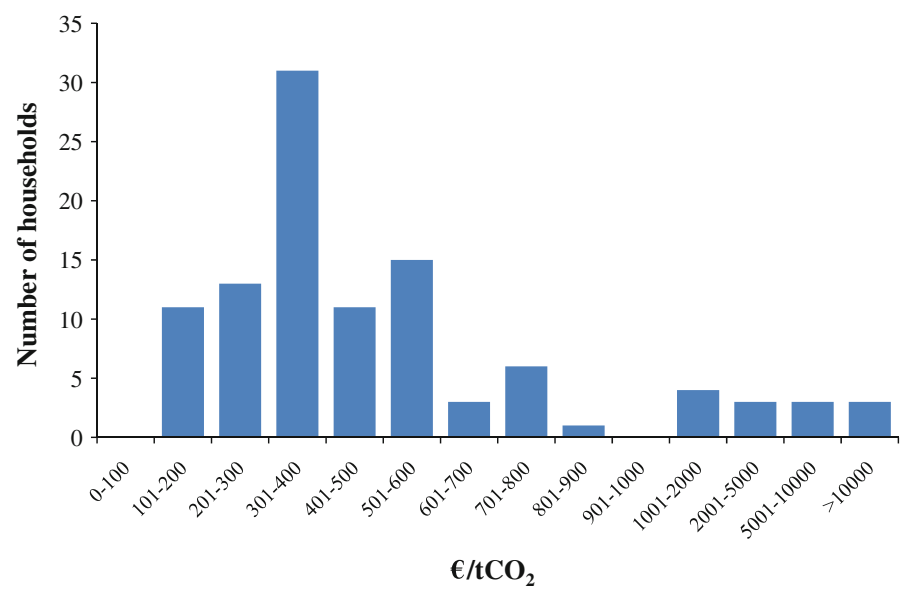

Fig. 2 Cost per $\mathrm{tCO}_{2}$ avoided per household: wood gasification boilers

Table 3 Descriptive statistics: biomass boilers and wood gasification boilers

a Annual cost discounted at $4 \%$ over 20 years

\begin{tabular}{lrc}
\hline & $\begin{array}{l}\text { Biomass } \\
\text { boilers }\end{array}$ & $\begin{array}{l}\text { Wood gasification } \\
\text { boilers }\end{array}$ \\
\hline Number of installations & 3,336 & 104 \\
Total amount in grants $(€)$ & $13,307,600$ & 208,000 \\
Average subsidy $\left(€ / \mathrm{CO}_{2}\right)^{\mathrm{a}}$ & 316 & 227 \\
Standard deviation $\left(€ / \mathrm{CO}_{2}\right)^{\mathrm{a}}$ & 1,929 & 1,179 \\
Minimum cost $\left(€ / \mathrm{tCO}_{2}\right)^{\mathrm{a}}$ & 5 & 4 \\
Maximum cost $\left(€ / \mathrm{tCO}_{2}\right)^{\mathrm{a}}$ & 14,841 & 7,067 \\
Median cost $\left(€ / \mathrm{tCO}_{2}\right)^{\mathrm{a}}$ & 30 & 13 \\
\hline
\end{tabular}

4.2 Relating the subsidy to replaced emissions of the household

Figure 3 compares the subsidies that households currently receive to the subsidies that would be received were they proportional to the household's level of emission reduction. The graph shows that some households would receive a subsidy that is near zero because the current emission levels of those households are low. These households tend to use natural gas for water heating, space heating and cooking. The accommodation may be relatively small in size, so that it is easier to heat or there may be fewer occupants. The accommodation may have been recently built and, therefore, complies with strict building regulations. Assuming all households still avail of the scheme, over $99 \%$ of households get a higher subsidy at present than they would if the subsidy was levied at $€ 15 / \mathrm{tCO}_{2} ; 1.2 \%$ of households would be better off at a subsidy level of $€ 20 / \mathrm{tCO}_{2}$ and this figure rises to $5 \%$ for a subsidy of $€ 30 / \mathrm{tCO}_{2}$. The relatively few households that benefit from an emissions related subsidy have very high levels of emissions at present. They tend to be larger households, the accommodation tends to be older and they are generally more difficult to heat. Also, they often employ very inefficient heating methods, such as an open fire. 


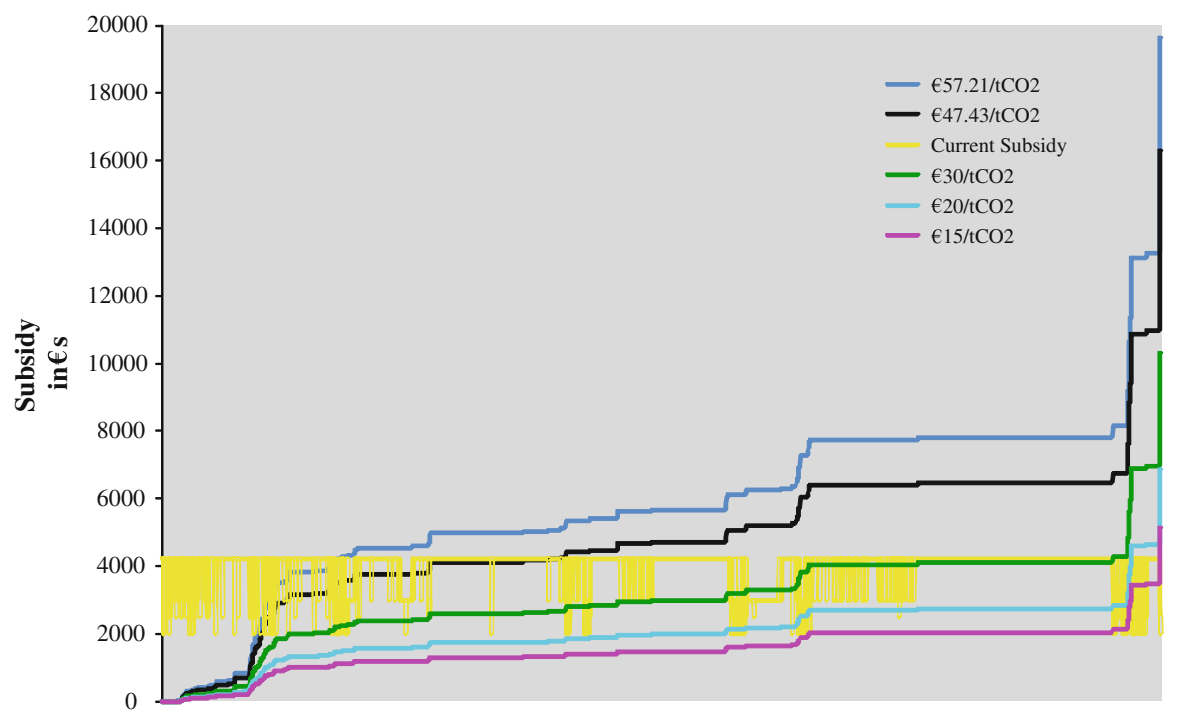

Fig. 3 Comparison of subsidy options

Table 10 shows the number of households that either gain or lose when the subsidy is related to the emissions level of the household. Results show that households receive a subsidy that is on average $€ 2,912$ higher than they would receive under the $€ 15 / \mathrm{tCO}_{2}$ scenario. Only 13 households would get a higher subsidy if emission reduction was priced at $€ 15 / \mathrm{tCO}_{2}$. They would gain an average of $€ 580$ compared to the current system. Under the $€ 20 / \mathrm{tCO}_{2}$ scenario, $98.8 \%$ of households would see their subsidy reduced by an average of $€ 2595$ compared to the present system, but 41 households would gain an average of $€ 704$. At a subsidy of $€ 30 / \mathrm{tCO}_{2}, 174$ households benefit. The remaining households get $€ 2,018$ more now than would be the case if the subsidy was levied at $€ 30 / \mathrm{tCO}_{2}$.

\subsection{Changes in demand as a result of changes in the subsidy}

It is reasonable to assume, however, that households would adjust their demand in response to a change in the level of subsidy. Using OLS regressions, we find that the price elasticity of demand for biomass boilers is $-0.88(0.02)$ and that for wood gasification boilers is $-1.87(0.11)$. As previously stated, only $5 \%$ of households gain if the subsidy was levied at $€ 30 / \mathrm{tCO}_{2}$ avoided. However, other high emission households may enter the scheme if the subsidy system was changed to an emissions related one. Similarly, households that have relatively low levels of emissions would see their subsidy fall and we would expect demand from these households to decrease. Table 4 shows how demand for the GHS changes as the subsidy changes. For presentation purposes, the table displays the average change in the level of demand exercised by different categories of households. There is large variation in 


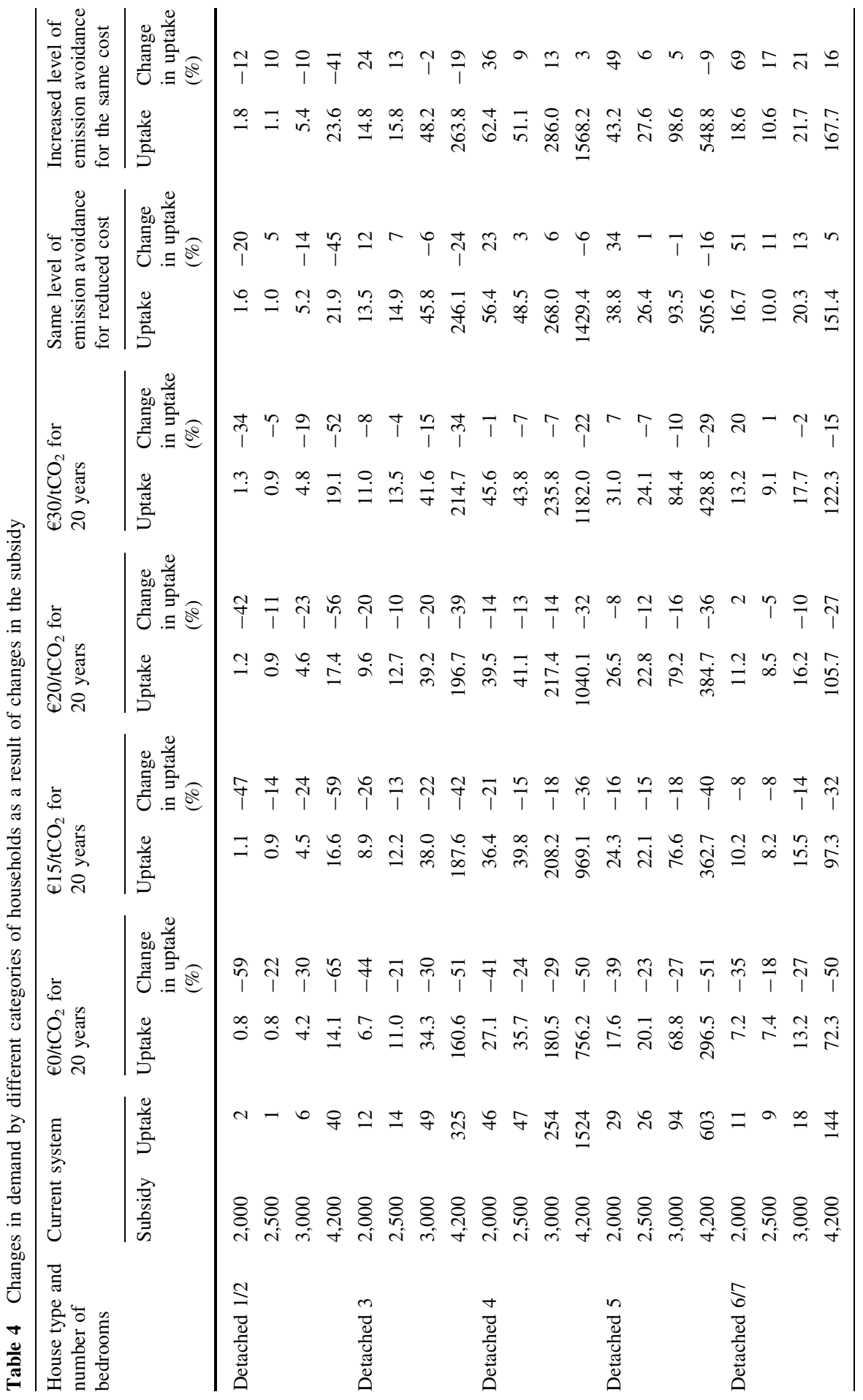




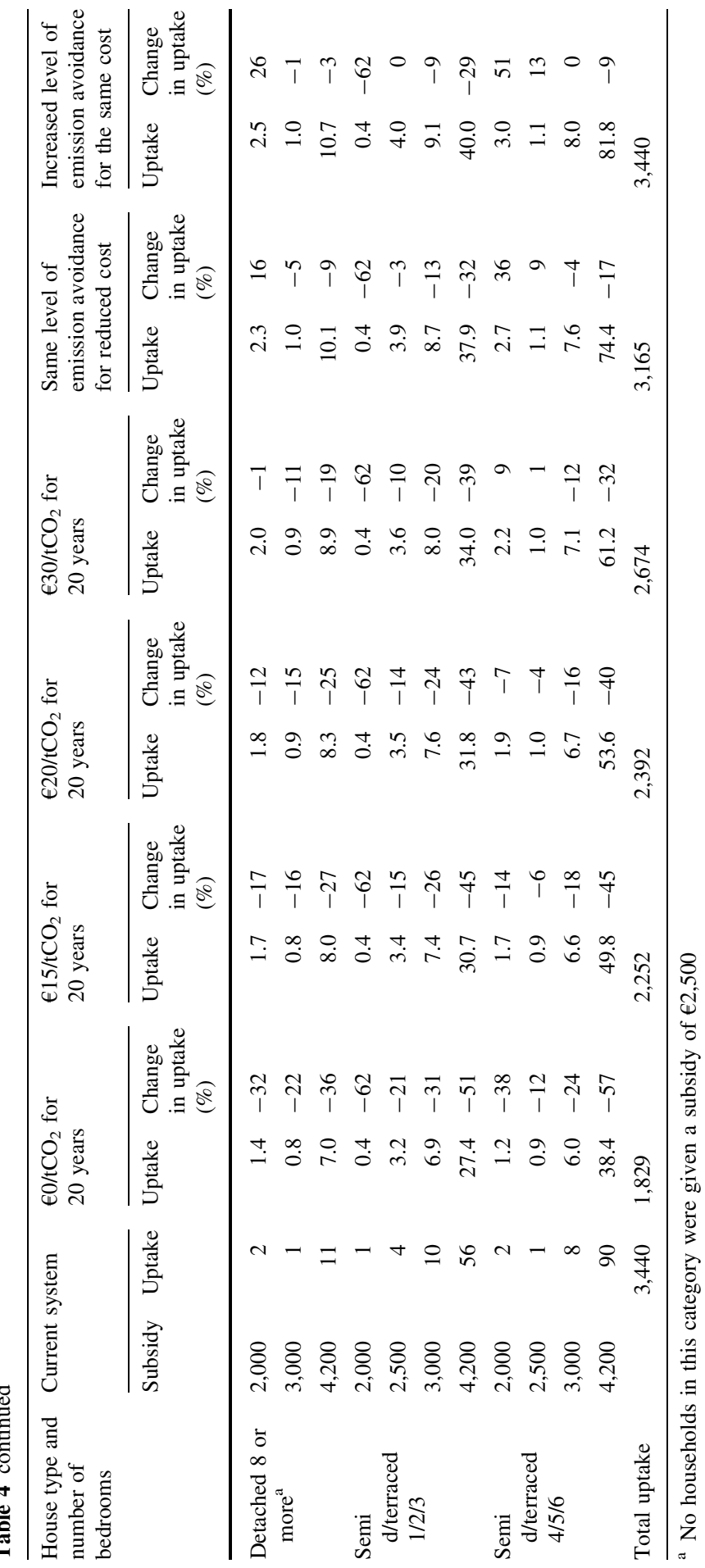


the degree to which demand changes across household categories. This occurs because of the variation in emissions levels, which, in turn, affects the degree to which the present value of the total subsidy awarded to each household will change.

We also consider the degree to which the GHS is economically and environmentally efficient. In one scenario, we assume that the budget for the scheme equals the current cost of the scheme for the restricted sample; $€ 13.5$ million and we simulate the maximum amount of emissions that can be avoided for this cost. An important assumption is that each household availing of the scheme receives the same subsidy per $\mathrm{tCO}_{2}$ avoided. We find that the subsidy in this case is $€ 57.21 / \mathrm{tCO}_{2}$. We also investigate the degree to which the cost can be reduced while reaching the same level of emission avoidance. The subsidy received by households in this case is $€ 47.43 / \mathrm{tCO}_{2}$. The number and profile of households availing of the scheme will change in each of these scenarios. The results are displayed in Table 4.

Figure 4 displays the degree to which the cost of the scheme and level of emission reduction changes. We find that by changing the current subsidy to one which is based on the emissions level of each household, the cost of the scheme can be reduced by $€ 2.3$ million and $17,383 \mathrm{tCO}_{2}$ can still be avoided per annum. On the other hand, if the budget of the scheme is $€ 13.5$ million, 1,679 extra tonnes of carbon dioxide could be avoided each year by making the subsidy payment efficient. These points are displayed in red in Fig. 4.

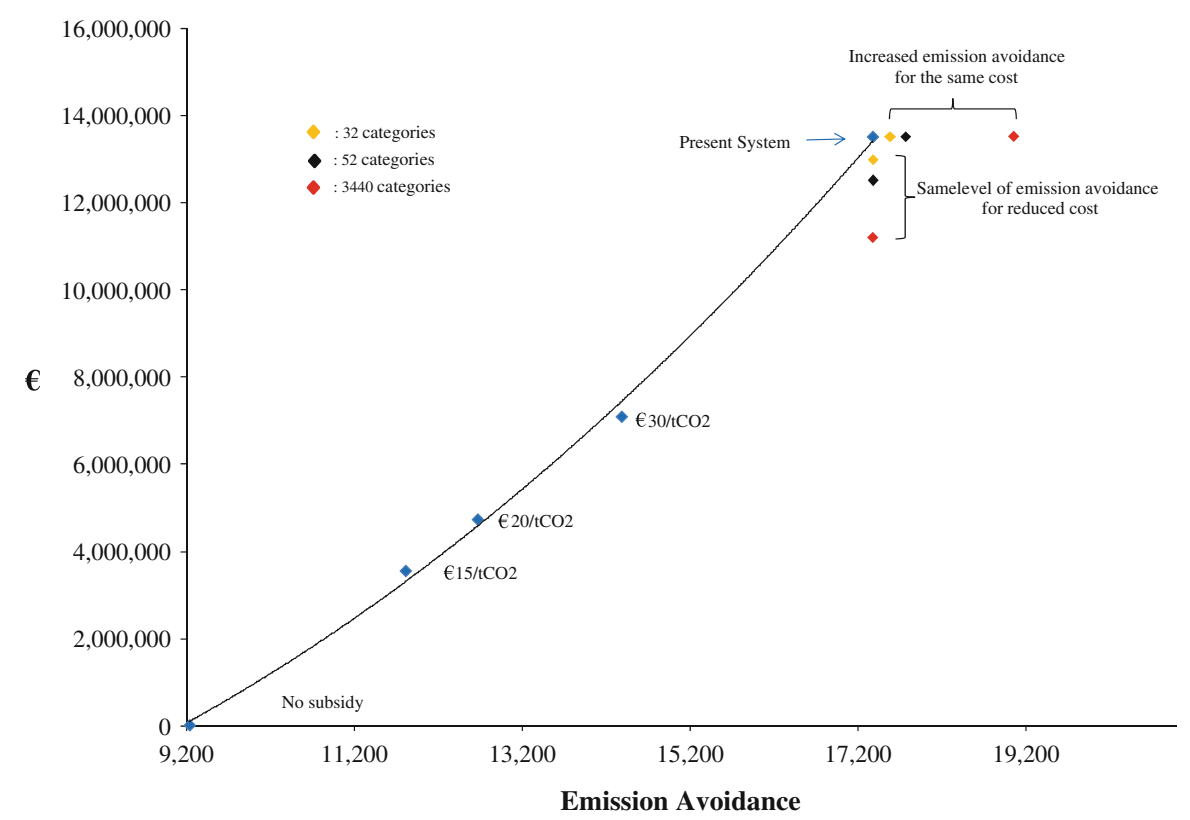

Fig. 4 Changes in cost and emission reduction resulting from subsidy changes (colour figure online) 
In the absence of any subsidy at all, 1,829 households would still have installed renewable energy technologies in their homes and the resulting level of emission avoidance would have been $9,239 \mathrm{tCO}_{2}$ per annum. The subsidies given to these households totalled over $€ 7$ million. Consequently, the budget of $€ 13.5$ million is only contributing to a reduction of $8,144 \mathrm{tCO}_{2}$ per annum rather than 17,383 . As explained earlier, emission reduction could be increased by $1,679 \mathrm{tCO}_{2}$ annually by changing the way the subsidy is awarded. Thus, the scheme is only 8,114/ $(8,114+1,679)=83 \%$ environmentally efficient. Regarding efficiency of exchequer spending, the same level of emission reduction could have been achieved with $€ 11.2$ million. Therefore, the scheme is only $11.2 / 13.5=83 \%$ economically efficient. The government overspends $17 \%$.

In the above, we treat each household in the GHS as a representative of a group of households in the HBS. Recall that energy use and emissions of households in the GHS were estimated based on the average energy usage and emissions levels of a group of similar households in the HBS. As a sensitivity analysis, we aggregate the GHS population into 32 groups and use the group's average as the representative household. Groups were chosen based on the subsidy received, the type of accommodation and the number of bedrooms. The yellow points in Fig. 4 show the results. The black points reflect the results that were derived when the GHS population was aggregated into 52 groups. This reveals the effect of heterogeneity on efficiency. The degree to which emission reduction can be increased for the same cost and the extent to which costs can be reduced for the same level of emission avoidance increases as the number of groups increases.

As another sensitivity analysis, we varied the price elasticities. We separately estimated the price elasticity for each of the 8 types of household outlined in Table 4. We then carry out the cost and emission reduction analyses on the restricted sample using the most extreme elasticities. ${ }^{7}$ The resulting changes in demand for the scheme, the cost of the scheme and the level of emission reduction are presented in Table 5 .

When demand is more elastic than it is in the base case, a small change in the level of subsidy can have a big effect on the number and type of households availing of the scheme. When demand is inelastic, the cost of the scheme is reduced substantially to $€ 8.6$ million while the same level of emission avoidance is reached. The subsidy in this case is $€ 36.30 / \mathrm{tCO}_{2}$. At this price, low emission households see a relatively large fall in the total subsidy they receive, but because demand is inelastic, the total number of households availing of the scheme falls only slightly. High emission households are always encouraged to avail of the scheme when the subsidy is emissions related. Thus, the same level of emission reduction is reached at a much lower cost. With inelastic demand, the level of emission reduction only increases slightly because households do not adequately adjust their demand in response to an increase in the level of the subsidy. When demand is elastic, emission reduction reaches a higher level of $21,111 \mathrm{tCO}_{2}$ per annum. If no subsidy is provided and if demand is elastic, no households avail of the scheme. However, if

\footnotetext{
${ }^{7}$ We also carried out the analysis using the upper and lower bound of the standard error for the elasticities used in the base case; however, standard errors were small and the analysis was not very informative.
} 
Table 5 Cost and emission scenarios under different price elasticities

\begin{tabular}{|c|c|c|c|c|}
\hline PED & $€ / \mathrm{tCO}_{2}$ & $\begin{array}{l}\text { Annual emission } \\
\text { reduction }\left(\mathrm{tCO}_{2}\right)\end{array}$ & $\begin{array}{l}\text { Total cost } \\
(€)\end{array}$ & $\begin{array}{l}\text { Household } \\
\text { demand }\end{array}$ \\
\hline \multicolumn{5}{|l|}{ Wood -1.87 , biomass -0.88} \\
\hline Current system & Various & 17,383 & $13,515,600$ & 3,440 \\
\hline $\begin{array}{l}\text { Same level of emission avoidance for } \\
\text { reduced cost }\end{array}$ & 47.43 & 17,383 & $11,205,686$ & 3,165 \\
\hline $\begin{array}{l}\text { Increased level of emission avoidance } \\
\text { for the same cost }\end{array}$ & 57.21 & 19,061 & $13,515,600$ & 3,440 \\
\hline No subsidy & 0 & 9,239 & 0 & 1,829 \\
\hline$€ 15 / \mathrm{tCO}_{2}$ & 15 & 11,814 & $3,543,636$ & 2,252 \\
\hline$€ 20 / \mathrm{tCO}_{2}$ & 20 & 12,673 & $4,724,848$ & 2,392 \\
\hline$€ 30 / \mathrm{tCO}_{2}$ & 30 & 14,390 & $7,087,272$ & 2,674 \\
\hline \multicolumn{5}{|l|}{ Wood -2.3 , biomass -2.23} \\
\hline $\begin{array}{l}\text { Same level of emission avoidance for } \\
\text { reduced cost }\end{array}$ & 48.36 & 17,383 & $11,423,738$ & 2,772 \\
\hline $\begin{array}{l}\text { Increased level of emission avoidance } \\
\text { for the same cost }\end{array}$ & 57.21 & 21,111 & $13,515,600$ & 3,387 \\
\hline No subsidy & 0 & $-2,972$ & 0 & -587 \\
\hline$€ 15 / \mathrm{tCO}_{2}$ & 15 & 3,342 & $3,543,636$ & 455 \\
\hline$€ 20 / \mathrm{tCO}_{2}$ & 20 & 5,447 & $4,724,848$ & 802 \\
\hline$€ 30 / \mathrm{tCO}_{2}$ & 30 & 9,656 & $7,087,272$ & 1,497 \\
\hline \multicolumn{5}{|l|}{ Wood -1.01 , biomass -0.04} \\
\hline $\begin{array}{l}\text { Same level of emission avoidance for } \\
\text { reduced cost }\end{array}$ & 36.30 & 17,383 & $8,575,600$ & 3,419 \\
\hline $\begin{array}{l}\text { Increased level of emission avoidance } \\
\text { for the same cost }\end{array}$ & 57.21 & 17,659 & $13,515,600$ & 3,461 \\
\hline No subsidy & 0 & 16,906 & 0 & 3,346 \\
\hline$€ 15 / \mathrm{tCO}_{2}$ & 15 & 17,103 & $3,543,636$ & 3,376 \\
\hline$€ 20 / \mathrm{tCO}_{2}$ & 20 & 17,169 & $4,724,848$ & 3,386 \\
\hline$€ 30 / \mathrm{tCO}_{2}$ & 30 & 17,300 & $7,087,272$ & 3,406 \\
\hline
\end{tabular}

demand is very inelastic, there will be a slight increase in the demand for the scheme compared to the present system.

\subsection{Welfare analysis}

We measure the level of satisfaction that consumers derive from the GHS by estimating each household's consumer surplus. ${ }^{8}$ Consumer surplus is the difference between the price a consumer is willing to pay and the price she actually pays.

\footnotetext{
${ }^{8}$ Recall that we have data on the boiler, but not on fuel use.
} 
Table 6 Welfare analysis

\begin{tabular}{|c|c|c|c|c|}
\hline & $\begin{array}{l}\text { CS: no } \\
\text { subsidy }\end{array}$ & $\begin{array}{l}\text { CS: current } \\
\text { system }\end{array}$ & $\begin{array}{l}\text { CS: } 100 \% \\
\text { economically } \\
\text { efficient }\end{array}$ & $\begin{array}{l}\text { CS: } 100 \% \\
\text { environmentally } \\
\text { efficient }\end{array}$ \\
\hline Consumer surplus $(€)$ & $7,245,831$ & $17,519,686$ & $15,893,294$ & $18,254,751$ \\
\hline Average surplus $(€ / \mathrm{h})$ & 2,106 & 5,093 & 4,620 & 5,307 \\
\hline Standard deviation $(€ / \mathrm{h})$ & 1,531 & 1,855 & 3,731 & 4,427 \\
\hline \multicolumn{5}{|l|}{ Producer surplus } \\
\hline Standard boilers & Unknown & Smaller & Smaller & Smaller \\
\hline Climate-friendly boilers & Unknown & Larger & Larger & Larger \\
\hline Cost to exchequer $(€)$ & 0 & $13,515,600$ & $11,205,686$ & $13,515,600$ \\
\hline Economic gain $(€)$ & $7,245,831$ & $4,004,086$ & $4,687,608$ & $4,739,151$ \\
\hline Emissions $\left(\mathrm{tCO}_{2} / \text { year }\right)^{\mathrm{a}}$ & 9,239 & 17,383 & 17,383 & 19,062 \\
\hline Net social gain $(€)$ & $7,384,416$ & $4,264,831$ & $4,948,353$ & $5,025,081$ \\
\hline
\end{tabular}

${ }^{\text {a }}$ Emissions are valued at $€ 15 / \mathrm{tCO}_{2}$

We do not have the information required to estimate producer surplus. The subsidy on biomass and wood gasification boilers increases the producer surplus for their manufacturers. However, households do not buy more boilers. The producer surplus of the manufacturers of traditional boilers thus falls. One could argue that the producer surplus is larger on a more advanced, subsidised product-so that the net change in producer surplus would be positive-but we have no data on the size.

We estimate the consumer surplus under the current system of subsidisation as well as in the scenarios in which the scheme is environmentally or economically efficient. Some statistics are shown in Table 6. The total consumer surplus is highest when environmental efficiency is maximised. The average consumer surplus is also highest in this case, but the standard deviation is large. This happens because the subsidy is emissions related. High emission households will benefit compared to the current system, but low emission households will not. Both the total and average consumer surpluses are higher under the current system than in the case where economic efficiency is maximised. This happens because economic efficiency results in fewer households availing of the scheme and some households would receive lower subsidies than they do under the current system.

Table 6 also shows the subsidies and the net social gain (abstracting from the producer surplus). The current GHS generates a consumer surplus of $€ 17.5$ million at a cost to the exchequer of $€ 13.5$ million. There is a net gain of $€ 4$ million. However, without a subsidy, the net gain would be €7.2 million. The GHS thus destroys welfare (unless the change in producer surplus is large and positive). An economically efficient subsidy would generate a net gain of $€ 4.7$ million-still loss making. Adding the environmental benefits ${ }^{9}$ hardly changes the results. On comparing the current subsidy with the best subsidy (none), the economic efficiency is $58 \%$.

\footnotetext{
${ }^{9}$ Carbon dioxide is valued at $€ 15 / \mathrm{tCO}_{2}$, the shadow price of carbon set by the EU ETS. $€ 15 / \mathrm{tCO}_{2}$ is close to the central estimate of the social cost of carbon for a $1 \%$ pure rate of time preference (Tol 2009).
} 


\section{Discussion and Conclusion}

In this paper, we present an ex-post estimate of the cost of carbon dioxide emission reduction using administrative micro-data from the GHS in the Republic of Ireland. The GHS subsidises the purchase of heating systems that use renewable energy. We focus on biomass and wood gasification boilers. The subsidy is independent of the amount or type of fuel replaced. The subsidy per tonne of carbon dioxide avoided therefore varies considerably between households. We use the data to estimate price elasticities and construct a simulation model that we use to optimise the subsidy. We find that it is possible to achieve the same emission reduction with $17 \%$ less exchequer spending, and that it is possible to achieve $17 \%$ more emission reduction for the same subsidy. $53 \%$ of the emissions avoided by bioenergy boilers would have been avoided without any subsidy. Although the subsidy has benefits for consumers and the environment, this comes at a cost to the exchequer; the subsidy reduces net social gain (excluding producer surplus) by $42 \%$.

The GHS is a small subsidy in a small country. The total costs and avoided emission are therefore small. However, the relatives are substantial. It could well be that other greenhouse gas emission reduction programmes in other countries are just as badly designed as the GHS and there are a number of factors that we have left out of the analysis. First, we focused on bioenergy boilers, omitting the larger but probably less effective subsidies for heat pumps and solar thermal. Second, we ignore the interaction of the subsidy for renewable heat with the subsidy for home insulation and the carbon tax on oil and gas. Third, we do not consider the lack of coordination of the bioenergy subsidies with other instruments to reduce greenhouse gas emissions and promote renewable energy. Fourth, we ignore the interactions of the renewable heat subsidy with other taxes (excises, VAT). Therefore, ours is an underestimate of the true inefficiency.

Besides highlighting the suboptimal design of one particular aspect of climate policy in one particular country, the paper also shows that administrative micro-data can be used for an ex-post evaluation of policy interventions. Studies like these should be conducted for other programmes and other countries so that we can obtain an estimate of the costs of actual emission reduction policy.

Acknowledgments The Energy Policy Research Centre of the Economic and Social Research Institute provided financial support. Edgar Morgenroth and an anonymous referee had excellent comments on an earlier draft.

Open Access This article is distributed under the terms of the Creative Commons Attribution License which permits any use, distribution, and reproduction in any medium, provided the original author(s) and the source are credited.

\section{Appendix}

See Tables 7, 8, 9, and 10 . 
Table 7 Demand for renewable technologies under the Greener Homes Scheme

\begin{tabular}{|c|c|c|c|c|c|c|c|c|c|c|}
\hline \multirow[t]{2}{*}{ Technology } & \multicolumn{2}{|l|}{2006} & \multicolumn{2}{|l|}{2007} & \multicolumn{2}{|l|}{2008} & \multicolumn{2}{|l|}{2009} & \multicolumn{2}{|l|}{2010} \\
\hline & Freq. & $\begin{array}{l}\text { Cost } \\
€ 000 \mathrm{~s}\end{array}$ & Freq. & $\begin{array}{l}\text { Cost } \\
€ 000 \mathrm{~s}\end{array}$ & Freq. & $\begin{array}{l}\text { Cost } \\
€ 000 \mathrm{~s}\end{array}$ & Freq. & $\begin{array}{l}\text { Cost } \\
€ 000 \mathrm{~s}\end{array}$ & Freq. & $\begin{array}{l}\text { Cost } \\
€ 000 \mathrm{~s}\end{array}$ \\
\hline $\begin{array}{l}\text { Air source heat } \\
\text { pump }\end{array}$ & 308 & 1,232 & 364 & 1,360 & 269 & 537 & 72 & 145 & 26 & 52 \\
\hline $\begin{array}{l}\text { Horizontal ground } \\
\text { collector heat } \\
\text { pump }\end{array}$ & 1,549 & 6,661 & 1,034 & 4,160 & 590 & 1,475 & 42 & 105 & 14 & 35 \\
\hline $\begin{array}{l}\text { Vertical ground } \\
\text { collector heat } \\
\text { pump }\end{array}$ & 505 & 3,280 & 563 & 3,439 & 335 & 1,178 & 43 & 144 & 5 & 18 \\
\hline $\begin{array}{l}\text { Water (well) to } \\
\text { water heat pump }\end{array}$ & 43 & 187 & 46 & 187 & 37 & 93 & 7 & 18 & 1 & 3 \\
\hline Biomass boiler & 2,411 & 10,100 & 1,215 & 4,930 & 454 & 1,323 & 49 & 123 & 10 & 25 \\
\hline Biomass stove & 362 & 399 & 360 & 396 & 218 & 212 & 141 & 113 & 37 & 30 \\
\hline $\begin{array}{l}\text { Biomass stove } \\
\text { with back boiler }\end{array}$ & 272 & 490 & 146 & 263 & 109 & 177 & 64 & 90 & 23 & 32 \\
\hline $\begin{array}{l}\text { Wood gasification } \\
\text { boiler }\end{array}$ & - & - & - & - & 46 & 92 & 59 & 118 & 11 & 22 \\
\hline $\begin{array}{l}\text { Solar evacuated } \\
\text { tube }\end{array}$ & - & - & 330 & 396 & 2,317 & 2,800 & 2,152 & 2,606 & 902 & 1,056 \\
\hline Solar flat plate & - & - & 675 & 902 & 3,496 & 4,597 & 1,832 & 2,368 & 1,026 & 1,270 \\
\hline $\begin{array}{c}\text { Solar thermal for } \\
\text { hot water and } \\
\text { space heating }\end{array}$ & 191 & 451 & 177 & 411 & 1 & 2 & - & - & - & - \\
\hline $\begin{array}{l}\text { Solar thermal for } \\
\text { hot water only }\end{array}$ & 2,026 & 3,266 & 3,189 & 5,022 & 1 & 2 & - & - & - & - \\
\hline Total & 7,667 & 26,065 & 8,099 & 21,465 & 7,873 & 12,485 & 4,461 & 5,828 & 2,055 & 2,542 \\
\hline
\end{tabular}

Table 8 Greener Homes Scheme grants 2006-2010

\begin{tabular}{llllll}
\hline Technology & Subsidy & Year & $\begin{array}{l}\text { Average } \\
\text { installation } \\
\text { cost }\end{array}$ & $\begin{array}{l}\text { Standard } \\
\text { deviation }\end{array}$ & $\begin{array}{l}\text { Installation cost } \\
\text { estimated by } \\
\text { SEAI }\end{array}$ \\
\hline $\begin{array}{l}\text { Air source heat } \\
\text { pump }\end{array}$ & $€ 4,000$ & $\begin{array}{c}\text { Apr 2006-Oct } \\
\text { 2007 }\end{array}$ & $€ 14,955$ & $€ 7,772$ & $€ 12,000-€ 13,000$ \\
& $€ 2,000$ & Oct 2007-2010 & & \\
$\begin{array}{l}\text { Horizontal ground } \\
\text { collector heat } \\
\text { pump }\end{array}$ & $€ 4,300$ & Apr 2006-Oct & $€ 18,358$ & $€ 7,048$ & $€ 13,000-€ 15,000$ \\
$\begin{array}{l}\text { Vertical ground } \\
\text { collector heat }\end{array}$ & $€ 2,500$ & Oct 2007-2010 & & \\
pump & $€ 3,500$ & Apr 2006-Oct & $€ 21,940$ & $€ 9,344$ & $€ 18,000-€ 21,000$ \\
\hline
\end{tabular}


Table 8 continued

\begin{tabular}{|c|c|c|c|c|c|}
\hline Technology & Subsidy & Year & $\begin{array}{l}\text { Average } \\
\text { installation } \\
\text { cost }\end{array}$ & $\begin{array}{l}\text { Standard } \\
\text { deviation }\end{array}$ & $\begin{array}{l}\text { Installation cost } \\
\text { estimated by } \\
\text { SEAI }\end{array}$ \\
\hline \multirow[t]{2}{*}{$\begin{array}{l}\text { Water (well) to water } \\
\text { heat pump }\end{array}$} & $€ 4,300$ & $\begin{array}{l}\text { Apr 2006-Oct } \\
2007\end{array}$ & \multirow[t]{2}{*}{$€ 16,898$} & \multirow[t]{2}{*}{$€ 7,604$} & \multirow[t]{2}{*}{$€ 12,000-€ 14,000$} \\
\hline & $€ 2,500$ & Oct $2007-2010$ & & & \\
\hline \multirow[t]{3}{*}{ Biomass boiler } & $€ 4,200$ & $\begin{array}{l}\text { Apr 2006-Oct } \\
2007\end{array}$ & \multirow[t]{3}{*}{$€ 9,553$} & \multirow[t]{3}{*}{$€ 5,264$} & \multirow[t]{3}{*}{$€ 10,000-€ 16,000$} \\
\hline & $€ 3,000$ & $\begin{array}{l}\text { Oct } 2007-\text { Aug } \\
2008\end{array}$ & & & \\
\hline & $€ 2,500$ & Aug 2008-2010 & & & \\
\hline \multirow[t]{2}{*}{ Biomass stove } & $€ 1,100$ & $\begin{array}{l}\text { Apr 2006-Aug } \\
2008\end{array}$ & \multirow[t]{2}{*}{$€ 3,127$} & \multirow[t]{2}{*}{$€ 31$} & \multirow[t]{2}{*}{$€ 2,000-€ 5,000$} \\
\hline & $€ 800$ & Aug 2008-2010 & & & \\
\hline \multirow[t]{2}{*}{$\begin{array}{l}\text { Biomass stove with } \\
\text { back boiler }\end{array}$} & $€ 1,800$ & $\begin{array}{l}\text { Apr 2006-Aug } \\
2008\end{array}$ & \multirow[t]{2}{*}{$€ 5,587$} & \multirow[t]{2}{*}{$€ 3,400$} & \multirow[t]{2}{*}{$€ 4,000-€ 6,000$} \\
\hline & $€ 1,400$ & Aug 2008-2010 & & & \\
\hline $\begin{array}{l}\text { Wood gasification } \\
\text { boiler }\end{array}$ & $€ 2,000$ & July 2008-2010 & $€ 10,720$ & $€ 3,967$ & $€ 10,000-€ 16,000$ \\
\hline Solar evacuated tube & $\begin{array}{l}€ 300 \text { per } \mathrm{m}^{2} \\
\text { (to max. } \\
6 \mathrm{~m}^{2} \text { ) }\end{array}$ & 2006-2010 & $€ 5,915$ & $€ 2,861$ & $€ 800-€ 1,300$ \\
\hline Solar flat plate & $\begin{array}{l}€ 250 \text { per } \mathrm{m}^{2} \\
\text { (to max. } \\
6 \mathrm{~m}^{2} \text { ) }\end{array}$ & 2006-2010 & $€ 6,505$ & $€ 3,112$ & $€ 800-€ 1,300$ \\
\hline $\begin{array}{l}\text { Solar thermal for hot } \\
\text { water and space } \\
\text { heating }\end{array}$ & $\begin{array}{l}€ 300 \text { per } \mathrm{m}^{2} \\
\text { (to max. } \\
6 \mathrm{~m}^{2} \text { ) }\end{array}$ & 2006-2010 & $€ 10,694$ & $€ 6,508$ & $€ 800-€ 1,300$ \\
\hline $\begin{array}{l}\text { Solar thermal for hot } \\
\text { water only }\end{array}$ & $\begin{array}{l}€ 300 \text { per } \mathrm{m}^{2} \\
\text { (to max. } \\
6 \mathrm{~m}^{2} \text { ) }\end{array}$ & 2006-2010 & $€ 7,016$ & $€ 4,612$ & $€ 800-€ 1,300$ \\
\hline
\end{tabular}

Table 9 Growth factor in energy use for new builds compared to 2005

\begin{tabular}{llll}
\hline Year & $\begin{array}{l}\text { Adjustment } \\
\text { factor: electricity }\end{array}$ & $\begin{array}{l}\text { Adjustment factor: } \\
\text { space heating }\end{array}$ & $\begin{array}{l}\text { Adjustment factor: } \\
\text { total energy }\end{array}$ \\
\hline 2009 & 1.43 & 0.55 & 0.71 \\
2008 & 1.38 & 0.81 & 0.89 \\
2007 & 1.29 & 1 & 1.03 \\
2006 & 1.19 & 1.01 & 1.04 \\
2005 & 1 & 1 & 1 \\
\hline
\end{tabular}


Table 10 Subsidy options

\begin{tabular}{lrrrr}
\hline & $\begin{array}{c}\text { Current } \\
\text { subsidy }\end{array}$ & $€ 15 / \mathrm{tCO}_{2}^{\mathrm{a}}$ & $€ 20 / \mathrm{tCO}_{2}^{\mathrm{a}}$ & $€ 30 / \mathrm{tCO}_{2}^{\mathrm{a}}$ \\
\hline Total cost $(€)$ & $13,515,600$ & $3,543,636$ & $4,724,848$ & $7,087,272$ \\
Average per household $(€)$ & 3,929 & 1,030 & 1,374 & 2,060 \\
Standard deviation $(€)$ & 587 & 457 & 610 & 915 \\
$\begin{array}{l}\text { No. of households that gain from emissions related } \\
\quad \text { subsidy }\end{array}$ & & 13 & 41 & 174 \\
$\begin{array}{l}\text { Average gain }(€) \\
\text { No. of households that lose from emissions related } \\
\quad \text { subsidy }\end{array}$ & 580 & 704 & 925 \\
Average loss $(€)$ & & 3,427 & 3,399 & 3,266 \\
\hline
\end{tabular}

Prices are discounted at $4 \%$

a We assume that the appliance lasts for 20 years

\section{References}

Amstalden RW, Kost M, Nathani C, Imboden DM (2007) Economic potential of energy-efficient retrofitting in the Swiss residential building sector: the effects of policy instruments and energy price expectations. Energy Policy 35(3):1819-1829

Babiker MH, Metcalf GE, Reilly JM (2003) Tax distortions and global climate policy. J Environ Econ Manag 46:269-287

Baumol WJ (1972) On taxation and the control of externalities. Am Econ Rev 62(3):307-322

Clarke LE, Edmonds JA, Krey V, Richels RG, Rose S, Tavoni M (2009) International climate policy architectures: overview of the EMF22 international scenarios. Energy Econ 31(S2):S64-S81

Clinch JP, Healy JD (2001) Cost-benefit analysis of domestic energy efficiency. Energy Policy 29(2):113-124

CSO (2007a) Household Budget Survey 2004/2005. Central Statistics Office, Dublin. http://www. eirestat.cso.ie/surveysandmethodologies/surveys/housing_households/survey_hbs.htm

CSO (2007b) 2006 census results. Central Statistics Office, Dublin. http://www.cso.ie/census/

Department of Finance (2011). Project discount and inflation rates. http://www.finance.gov.ie/ Viewtxt.asp?DocID $=5387 \&$ CatID $=56 \& m=\&$ StartDate $=01+$ January +2008

Department of Social and Family Affairs (2009) Effectiveness of domestic energy-efficiency programmes. http://www.seai.ie/Grants/Warmer_Homes_Scheme/Fuel_Poverty_Action_Research_ Reports/executive_summary.pdf

Dineen D, Ó'Gallachóir B (2011) Modelling the impacts of building regulations and a property bubble on residential space and water heating. Energy Build 43(1):166-178

European Commission (2011). Renewable energy targets. http://ec.europa.eu/energy/renewables/targets_ en.htm

FitzGerald J, Bergin A, Conefrey T, Diffney S, Duffy D, Kearney I, Lyons S, Malaguzzi Valeri L, Mayor K, Tol R (2008) Medium-term review 2008-2015. Economic and Social Research Institute, Dublin. http://www.esri.ie/UserFiles/publications/20080515155545/MTR11.pdf

Jenkins DP (2010) The value of retrofitting carbon-saving measures into fuel poor social housing. Energy Policy 38(2):832-839

Leahy E, Lyons S (2010) Energy use and appliance ownership in Ireland. Energy Policy 38(8):4265-4279

Metcalf GE (2009) Tax policies for low-carbon technologies. Natl Tax J 62(3):519-533

Mills BF, Schleich J (2009) Profits or preferences? Assessing the adoption of residential solar thermal technologies. Energy Policy 37(10):4145-4154

O’Doherty J, Lyons S, Tol RSJ (2008) Energy-using appliances and energy-saving features: determinants of ownership in Ireland. Appl Energy 85(7):650-662 
O’Leary F, Howley M, Ó’Gallachóir B (2008) Energy in the residential sector, 2008 report. Sustainable Energy Authority of Ireland, Cork. http://www.seai.ie/News_Events/Press_Releases/Energy_in_ the_Residential_Sector_FNL.pdf

Oritz RA, Markandya A (2009) Which policy option can be more cost-effective in promoting the use of energy efficient appliances in Europe? A comparison of energy taxes, subsidies, tax credits and bans. Basque Centre for Climate Change, Bilbao. http//:www.bc3research.org/policy_briefings/ downpubli.html

Point Carbon (2011) Globally carbon markets gain one percent in value from 2009 to 2010. http:// www.pointcarbon.com/aboutus/pressroom/pressreleases/1.1496966

Scott S (1997) Household energy efficiency in Ireland: a replication study of ownership of energy saving items. Energy Econ 19(2):187-208

Scott S, Eakins J (2004) Carbon taxes: which households gain or lose? Environmental Protection Agency, Wexford. http://www.esri.ie/pdf/BKMNEXT043_Carbon\%20Taxes.pdf

SEAI (2010) Grants Greener Homes Scheme FAQ. http://www.seai.ie/Grants/GreenerHomes/FAQ/ \#chosen

SEAI (2011) Home Energy Saving scheme statistics. http://www.seai.ie/Grants/Home_Energy_Saving_ Scheme/HES_Statistics/

Tol RSJ (2009) The economic effects of climate change. J Econ Persp 23(2):29-51

Wasi N, Carson R (2011) The influence of rebate programs on the demand for water heaters: the case of New South Wales. Paper presented at the Australian Agricultural and Resource Economics Society Conference, February 8-11, 2011, Melbourne. http://ageconsearch.umn.edu/bitstream/100731/ 2/Wasi\%20N.pdf 